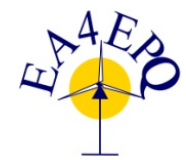

$19^{\text {th }}$ International Conference on Renewable Energies and Power Quality (ICREPQ'21)

Almería (Spain), $28^{\text {th }}$ to $30^{\text {th }}$ July 2021

Renewable Energy and Power Quality Journal (RE\&PQJ)

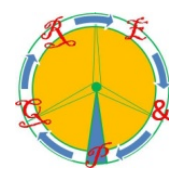

\title{
Grid access of non-synchronous generation: Review of the Spanish regulation
}

\author{
L. Rouco, E. Lobato \\ Universidad Pontificia Comillas \\ Alberto Aguilera, 23, 28015 Madrid, Spain
}

\begin{abstract}
The development of wind and solar photovoltaic generation depends critically on the access to the grid. In contrast to synchronous generation, the access to the grid of converter based generation (also called non-synchronous generation) is affected by a number of technical constraints. The Spanish regulation of the grid access of non-synchronous generation has been recently reformulated. This contribution will review the new regulation. The past regulation will be also discussed.
\end{abstract}

Keywords. Grid access, Non-synchronous generation, Short Circuit Ratio.

\section{Introduction}

Decarbonization of economies to fulfill the Paris agreement goals requires the development of huge amounts of renewable power generation. Wind and solar photovoltaic power generation technologies have become technically mature and economically competitive technologies.

The Spanish National Program of Energy and Climate foresees that the wind installed capacity will become 50 GW in 2030 from the current $27 \mathrm{GW}$ and that the solar photovoltaic installed capacity will become $39 \mathrm{GW}$ in 2030 from the current $11 \mathrm{GW}$ ([1], [2]).

Wind and solar photovoltaic generation are connected to the grid through power electronic converters. It results in formidable challenges for power system stability, control and protection. Due to such fact, it can be stated that ac power systems are facing the largest transformation since Edison, Tesla and Westinghouse.

The development of wind and solar photovoltaic generation depends critically on the access to the grid. In contrast to synchronous generation, the access to the grid of converter based generation (also called nonsynchronous generation) is affected by a number of technical constraints.

The Spanish regulation of the grid access of nonsynchronous generation has been recently reformulated. This paper reviews the new regulation ([3], [4]). The past regulation will be also discussed ([5], [6]). The past regulation was based exclusively on the Short Circuit
Ratio criterion [7]. The new regulation is based on the Weigthed Short Circuit criterion [8] together with steadystate and dynamic security assessments.

The paper is organized as follows. Section 2 reviews the past regulation. Section 3 details the new regulation. Section 4 provides the conclusions of the paper.

\section{Past regulation}

The first Spanish regulation on the connection of renewable energy sources to the grid dates from 1985. It was mainly aimed at addressing the connection of minihydro and cogeneration plants. A general requirement was that the capacity of the line should be greater than $50 \%$ of the nominal power of the plant in case of plants smaller than $5000 \mathrm{kVA}$. It also addresses the connection of induction generators imposing that the voltage drop due to their starting should not be higher than $5 \%$. In addition, the nominal power of wind generators should be smaller than $1 / 20$ the short circuit capacity of the grid to avoid excessive voltage variations due to wind speed variation

$$
\frac{P_{n}}{S_{s c}} \leq \frac{1}{20}
$$

where

$S_{s c}$ is the short circuit capacity (apparent power) of the grid in MVA and

$P_{n}$ is the nominal active power of the plant in MW

According to [7], the Short Circuit Ratio is defined

$$
S C R=\frac{S_{s c}}{P_{n}}
$$

Hence, requirement (1) can be formulated as

$$
S C R \geq 20
$$

The physical meaning of the SCR is discussed. If the grid is represented at the point of connection by is Thévenin equivalent (see Fig. 1), the SCR is the inverse of the short circuit impedance $Z_{s c}$ 


$$
S C R=\frac{1}{Z_{s c}(p u)}
$$

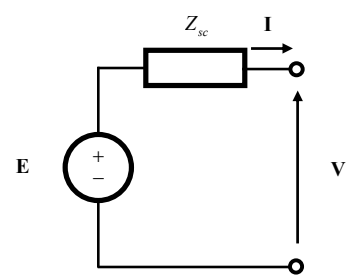

Fig. 1: Thévenin equivalent of the grid at the point of connection.

If the renewable power generator is connected to a low voltage grid (which grid impedance is resistive), the SCR is equal to the voltage variation when a generator that was suppling the nominal power with unity power factor trips (see Fig. 2).

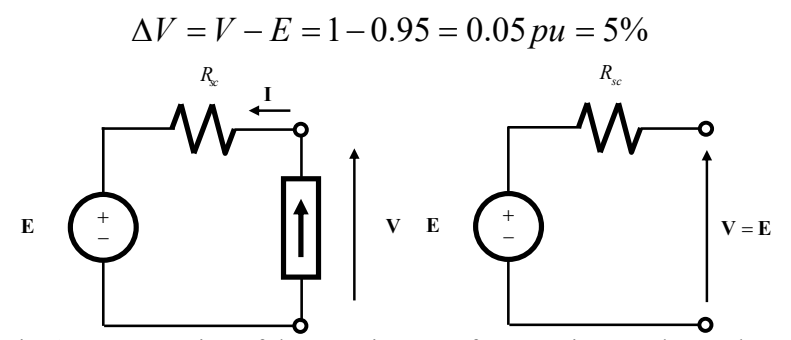

Fig. 2: Interpretation of the SCR in case of connection to a low voltage grid.

If the renewable power generator is connected to a high voltage grid (which grid impedance is inductive), the SCR is an upper bound equal to the voltage variation when a generator that was suppling the nominal power trips (see Fig. 3). Precisely if the power factor is 0.9 lagging, the voltage variation becomes $2.29 \%$.

$$
\begin{aligned}
& \mathbf{E}=\mathbf{V}-j X_{s c} \mathbf{I} \\
& =1.0-j 0.05 \cdot(1-j 0.4843) \\
& =0.9771 p u \\
& \Delta V=V-E=0.0229=2.29 \%
\end{aligned}
$$

$\mathbf{E}$

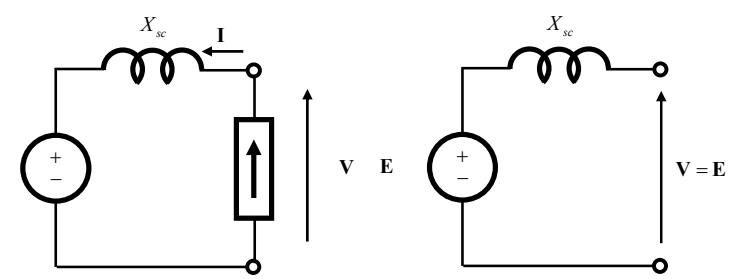

Fig. 3: Interpretation of the SCR in case of connection to a high voltage grid.

Royal Decree 413/2014 of 6 June extended to all nonmanageable renewable energy resources the requirement of the Ministry Order of 1985. Non-manageable renewable energy resources include wind and solar photovoltaic. It assumes that solar thermal is manageable. It does not consider the possibility of hybrid plants that make manageable wind or solar photovoltaic plants with the aid of energy storage systems.

The Spanish TSO periodically published the grid access capability. Fig. 4 shows the grid access capability according to the past regulation as published by the Spanish TSO on 30 April 2021 in La Rioja region [9]. La Rioja region has one $400 \mathrm{kV}$ and five $220 \mathrm{kV}$ buses.

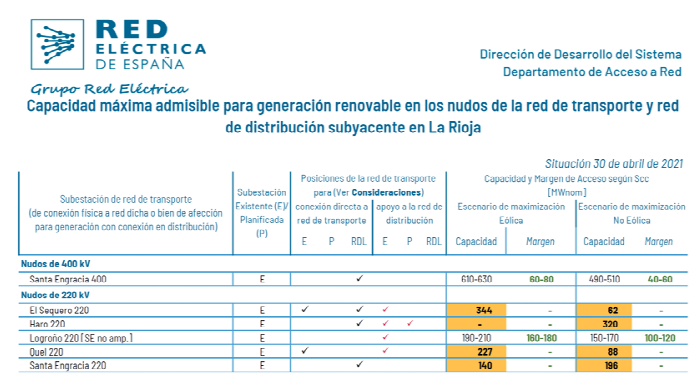

Fig. 4: Grid access capability according to the past regulation as published by the Spanish TSO on 31 April 2021 in La Rioja region.

\section{New regulation}

All stakeholders agreed that new regulation was needed to allow the grid integration of the large amount of renewable energy resources foreseen in the natioFig. 5nal plan on energy and climate (PNIEC). Works started in fall 2019 reviewing the SCR criterion. It must be noted that the Spanish power system is the only system (to the author's knowledge) that uses the SCR criterion to determine the grid access capability. The motivation for keeping the SCR criterion has been on the impact of grid strength on the stability of the controls of wind generators based on double fed induction (DFIGs). Fig. 5 shows root locus of as the SCR changes for two design options of the bandwidth of PLL controller: 0.2 and 0.3 of the bandwidth of the current controllers. It confirms that a pair of complex poles may become unstable when the grid is very weak.

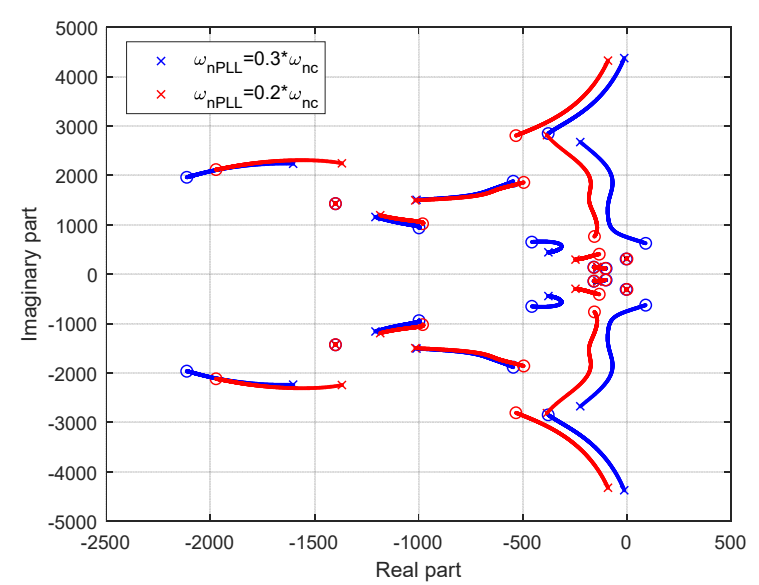

Fig. 5: Root locus of as the SCR changes for two design options of the bandwidth of PLL controller.

The new regulation comprises two pieces of legislation

- CNMC (National Comission for Markets and Competition) Circular 1/2021 of 20 January

- CNMC Resolution of 20 May 2021

CNMC Circular $1 / 2021$ of 20 January establishes that grid access capacity of asynchronous generation (generation connected to the grid through power electronic converters) is determined by three criteria 
- Short circuit capacity

- Static security

- Dynamic security

CNMC Resolution of 20 May 2021establishes detailed specifications for grid access capacity calculations to

- Transmission grid

- Distribution grids

\section{A. Grid access to transmission grids}

The grid access to the transmission grids is determined by short circuit capacity and static and dynamic security criteria. Transmission grid in mainland Spain is the grid at 400 and $220 \mathrm{kV}$. Transmission grid in the Spanish isolated systems is the grid at 220, 132 and $66 \mathrm{kV}$.

\section{1) Short circuit capacity}

The short circuit capacity criterion requires that Weighted Short Circuit Ratio (WSCR) of the power park modules within their area of influence should be greater than

- 10 when there are power park modules that do not fulfill EU Comission Regulation 2016/631 [11]

- 6 when all power park modules fulfill EU Comission Regulation 2016/631

The WSCR is defined as [8]

$$
W S C R=\frac{\sum_{i} S_{s c, i} \cdot P_{n, i}}{\left(\sum_{i} P_{n, i}\right)^{2}}
$$

The area of influence is determined using the Multi Infeed Influence Factor (MIFF) which is defined as ([12], [13])

$$
M I I F_{i j}=\frac{\Delta V_{i}}{\Delta V_{j}}
$$

The MIIFs can be calculated using either non-linear (power flow) of linear (short circuit) models of the power system as shown in Fig. 6.

The non-linear power system model is described by the linearized power flow equations in terms of the Jacobian matrix

$$
\left[\begin{array}{cc}
\frac{\partial \mathbf{P}}{\partial \boldsymbol{\theta}} & \frac{\partial \mathbf{P}}{\partial \mathbf{V}} \\
\frac{\partial \mathbf{Q}}{\partial \boldsymbol{\theta}} & \frac{\partial \mathbf{Q}}{\partial \mathbf{V}}
\end{array}\right]\left[\begin{array}{c}
\Delta \boldsymbol{\theta} \\
\Delta \mathbf{V}
\end{array}\right]=\mathbf{J}\left[\begin{array}{c}
\Delta \boldsymbol{\theta} \\
\Delta \mathbf{V}
\end{array}\right]\left[\begin{array}{c}
\Delta \mathbf{P} \\
\Delta \mathbf{Q}
\end{array}\right]
$$

Hence, MIIFs can be calculated as
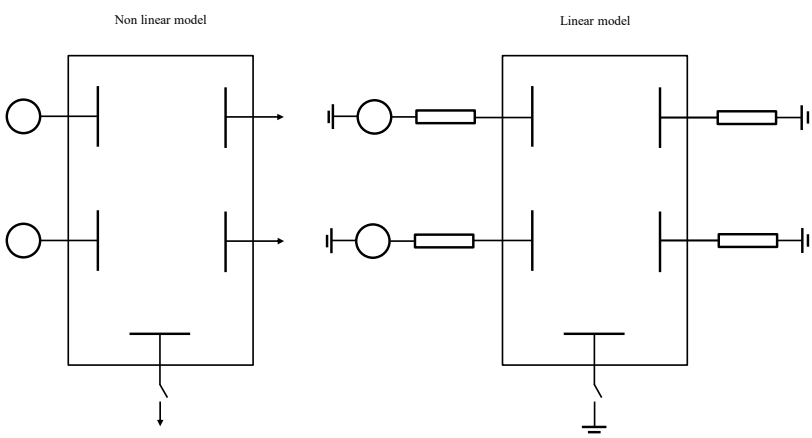

Fig. 6: Non-linear and linear power system models.

$$
M I I F_{i j}=\left.\frac{\Delta V_{j}}{\Delta V_{i}}\right|_{\Delta Q_{i}=1}=\frac{\mathbf{J}_{\Delta Q_{i}, \Delta V_{j}}^{-1}}{\mathbf{J}_{\Delta Q_{i}, \Delta V_{i}}^{-1}}
$$

The linear power system model is described by the nodal equations in terms of admittance matrix

$$
\begin{aligned}
& \mathbf{Y}_{b u s} \mathbf{V}=\mathbf{I} \\
& \mathbf{Z}_{b u s}=\mathbf{Y}_{b u s}^{-1}
\end{aligned}
$$

Hence, MIIFs can be calculated as

$$
\operatorname{MIIF}_{i j}=\left.\frac{\Delta V_{j}}{\Delta V_{i}}\right|_{\Delta I_{i}=1}=\frac{Z_{b u s, i j}}{Z_{b u s, i i}}
$$

We believe as [12] that the use of a power system linear model is much more helpful to understand physically the areas of influence.

Power park modules belong to the same area of influence if $M I I F_{i j}$ is greater than 0.98 . It is very interesting to note that the MIIF matrix is not symmetric. Let us consider a simple example to show it. Fig. 7 shows the single line diagram of the connection of a power park module to a $400 \mathrm{kV}$ grid through a $400 / 132 \mathrm{kV}$ transformer. The transformer nominal power and reactance are provided. The short circuit capacity of the $400 \mathrm{kV}$ grid is also provided.

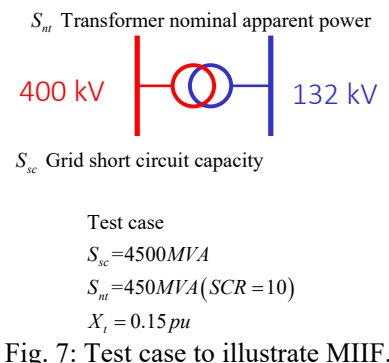

Fig. 8 shows the equivalent circuit of the test case of Fig. 7. 


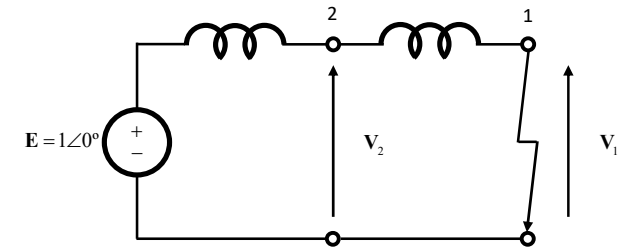

Fig. 8: Equivalent circuit of the test case used to illustrate MIIF.

The MIIFs are computed as follows

$$
\begin{aligned}
& \text { MIIF }_{12}= \frac{\Delta V_{2}}{\Delta V_{1}}=\frac{\frac{X_{t}}{X_{s c}+X_{t}}-1}{-1} \\
& \frac{\frac{0.15}{450}+0.15}{\frac{4500}{-1}}=0.4 \\
& \operatorname{MIIF}_{21}=\frac{\Delta V_{1}}{\Delta V_{2}}=\frac{0-1}{0-1}=1
\end{aligned}
$$

Hence the MIIF matrix becomes

$$
\text { MIIF }=\left[\begin{array}{ll}
1.0 & 0.4 \\
1.0 & 1.0
\end{array}\right]
$$

The MIIF must be transformed to a symmetric matrix as follows

$$
\mathbf{M I I F}_{\text {tranf }}=\left[\begin{array}{ll}
1.0 & 1.0 \\
1.0 & 1.0
\end{array}\right]
$$

It means that buses number 1 and 2 are within the same area of influence. This simple example indicates that power park modules connected radially to a transmission grid bus will always belong to the area of influence of such transmission grid bus.

\section{2) Steady-state security}

Fulfilment of the steady-state security criterion requires that the grid is able to evacuate the renewable plant production for $90 \%$ of the time. In other words, there is absence of non-admissible overloads in $\mathrm{N}$ and $\mathrm{N}-\mathrm{X}$ conditions as required in Operational Procedure 1.1 [14]. It means that congestion management measures could be applied during $10 \%$ the time. In addition, transmission grid development criteria imposed by Operational Procedure 13.1 are fulfilled [15].

The renewable plant ability of delivering its production $90 \%$ of the time is connected with requirements of article 13.5 of REGULATION (EU) 2019/94 [16] and the generation-duration curves of wind and solar PV sources (see Fig. 9).

The calculation procedure comprises the following steps

- Hourly simulation of the planning horizon year using a single bus generation model
- Selection of representative hours by clustering (it assigns a probability to each representative hour)

- Calculation of feasible productions using a generation-network model

CNMC Resolution of 20 May 2021 does not detail which is the assumed nominal power of each plant. We would assume that it is the nominal power calculated according to the short circuit capacity criterion.

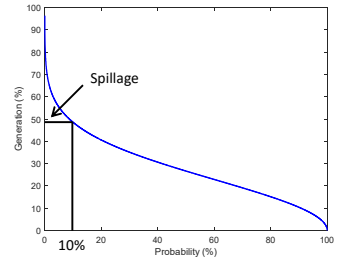

Wind

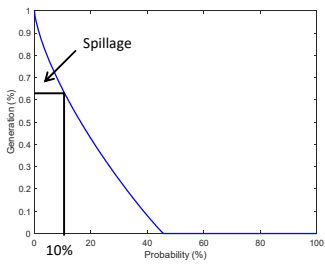

Solar PV
Fig. 9: Generation-duration curves of wind a solar PV and probability of spillage.

\section{3) Dynamic security}

Fulfilment of the dynamic-state security criterion requires that the critical clearing time of three phase fault at any bus should be greater $100 \mathrm{~ms}$. In addition, the following conditions that must be fulfilled in case of $250 \mathrm{~ms}$ three phase faults

- Admissible post-fault operating point

- No area loss of synchronism

- No tripping of any France-Spain interconnection tie

- Generation tripping smaller than $3000 \mathrm{MW}$

- Damping of synchronous generator oscillations greater than $5 \%$

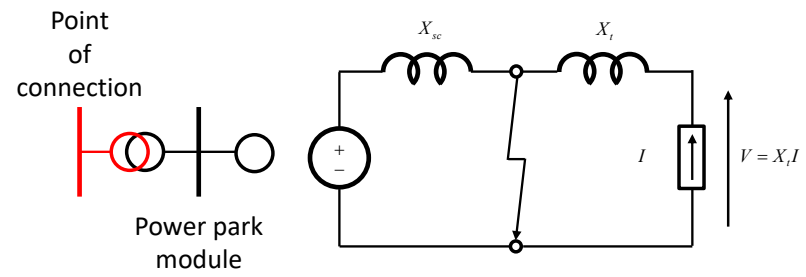

Fig. 10: Equivalent circuit of a power park module connected to the transmission grid in case of a three phase fault.

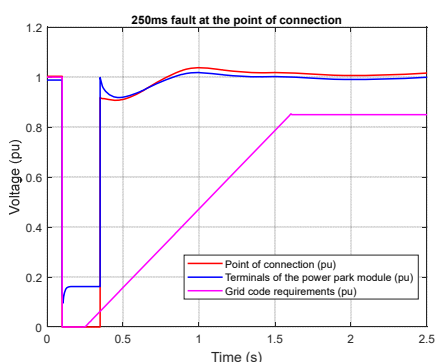

Fig. 11: Time domain simulation of a $250 \mathrm{~ms}$ three phase fault and the grid code requirement. 


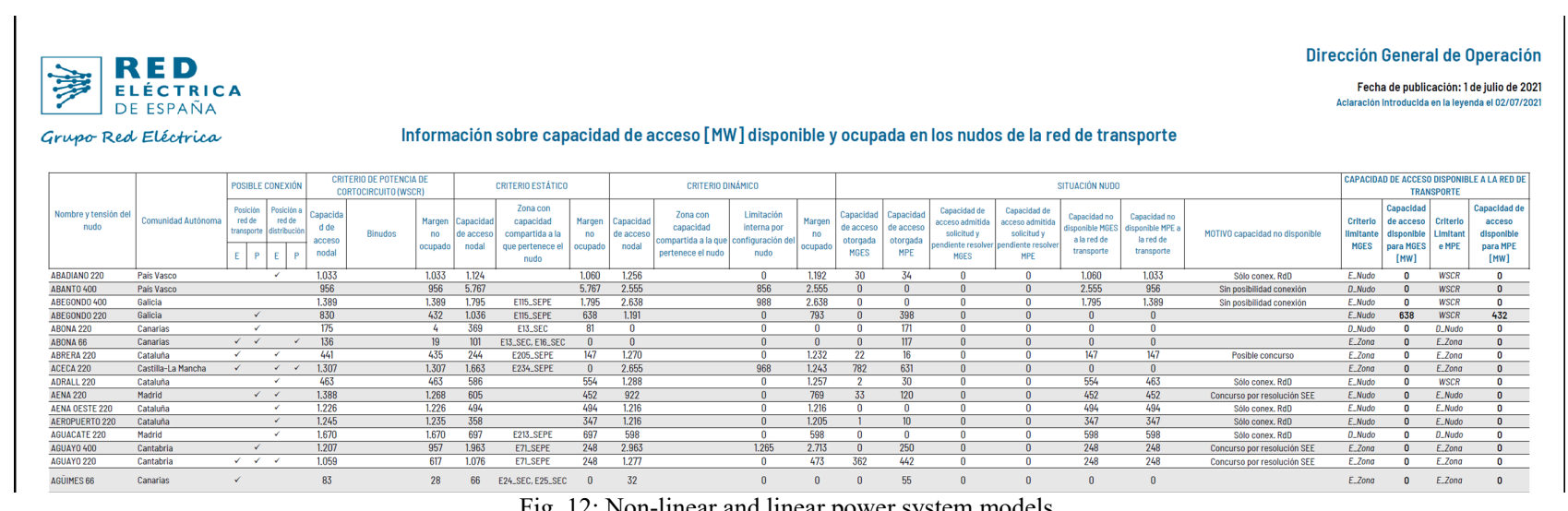

Fig. 12: Non-linear and linear power system models.

The Spanish implementation of the EU Commission Regulation 2016/631 [11] Order TED/749/2020, of 16 July [17]) imposes that power park modules do not disconnect from the grid in case of solid $150 \mathrm{~ms}$ three phase faults. However, Operational Procedure 13.1 [15]requires that above mentioned conditions are fulfilled in case of $250 \mathrm{~ms}$ three phase faults. The contradiction between both requirements is overcome thanks to the ability of power park modules to supply nominal reactive current in case of solid three phase faults. Fig. 10 shows the equivalent circuit that has to be considered to explain the voltage rise at the point of connection of the power park modules due to the supplied reactive current. Fig. 11 shows the results of the time domain simulation of a 250 $\mathrm{ms}$ three phase fault and the grid code requirement.

The Spanish TSO has published on 1 July 2021 the grid access capability according to the three aforementioned criteria [18]. Fig. 12 shows the grid access capability according to the new regulation as published by the Spanish TSO on 1 July 2021 for few sampled buses.

It is interesting to note that the disturbance that let to the incident occurred in Spanish mainland power system 24 July 2021 (the tripping of the interconnection ties with France) [19] was not considered within the catalogue of disturbances to be evaluated to ensure the dynamic security of the system.

\section{B. Grid access to distribution grids}

The minimum and the maximum nominal power of plant depend on distribution grid voltage as shown in Table I. In addition, the grid access to distribution grids is determined by short circuit capacity and static security criteria. Distribution grids in mainland Spain are the high voltage grids below $220 \mathrm{kV}$. Distribution grids in the Spanish isolated systems are the high voltage grids below $66 \mathrm{kV}$.

\section{4) Short circuit capacity}

In distribution grids, it is assumed that the area of influence contains only one node. Hence, the WSCR becomes the SCR

$$
W S C R=\frac{\sum_{i} S_{s c, i} \cdot P_{n, i}}{\left(\sum_{i} P_{n, i}\right)^{2}}=\frac{S_{s c} \cdot P_{n}}{P_{n}^{2}}=\frac{S_{s c}}{P_{n}}=S C R
$$

\section{5) Steady-state security}

Fulfilment of the steady-state security criterion requires that in both $\mathrm{N}$ and $\mathrm{N}-1$ conditions there is not unserved power, there are no overloads in either transmission lines or transformers and the voltages are within the admissible ranges. In addition, the admissible voltage excursions in case of

- Single generator connection and tripping are $>36 \mathrm{kV}: \pm 2,5 \%$

$<36 \mathrm{kV}: \pm 3 \%$

- Generators connected to a busbar tripping are $>36 \mathrm{kV}: \pm 4 \%$

$<36 \mathrm{kV}: \pm 5,5 \%$

Table I: Minimum and maximum admissible power.

\begin{tabular}{|c|c|c|c|}
\hline $\begin{array}{c}\text { Grid nominal } \\
\text { voltage (kV) }\end{array}$ & $\begin{array}{c}\text { Minimum } \\
\text { admisible } \\
\text { power in a } \\
\text { new position } \\
\text { of a } \\
\text { substatation }\end{array}$ & $\begin{array}{c}\text { Minimum } \\
\text { admisible } \\
\text { power by } \\
\text { opening a line }\end{array}$ & $\begin{array}{c}\text { Maximum } \\
\text { admisible } \\
\text { power in a } \\
\text { new position } \\
\text { of a } \\
\text { substation }\end{array}$ \\
\hline 132 & 10 & 12 & 100 \\
\hline 66 & 6 & 10 & 60 \\
\hline $50-55$ & 5 & 10 & 50 \\
\hline 45 & 4 & 7 & 40 \\
\hline 30 & 4 & 2 & 30 \\
\hline $24-25$ & 4 & - & 20 \\
\hline 20 & 4 & - & 15 \\
\hline$\leq 1$ and $\geq 15$ & 4 & - & 10 \\
\hline LV & - & - & 0,1 \\
\hline
\end{tabular}

\section{Conclusions}

Getting grid access is critical for the feasibility of the development of renewable power generation projects. Spanish regulation has recently changed (published in January and May 2021) The Spanish TSO has just published (1 July 2021) the grid access capability of each transmission grid node according to the new regulation. 
Promoters of renewable energy projects need to understand the new regulation to be able to perform grid access capability calculations. The transparency of the calculation method requires that the input data and assumptions made should be public and that the tools and methods should be approved. The ultimate purpose of a transparent approach is that all participants are at identical conditions. A transparent approach should avoid any information asymmetry results in illegitimate competitive advantages of some participants with respect to others. Information confidentiality should not be used as excuse to avoid transparency. Solutions based on the use of default models exists.

\section{References}

[1] Ministerio para la Transición Ecológica y el Reto Demográfico, Plan Nacional Integrado de Energía y Clima, https://www.miteco.gob.es/images/es/pnieccompleto_tcm30508410.pdf.

[2] Red Eléctrica de España, Informe del sistema eléctrico español 2020, https:/www.ree.es/es/datos/publicaciones/informe-anualsistema/informe-del-sistema-electrico-espanol-2020.

[3] Circular 1/2021, de 20 de enero, de la Comisión Nacional de los Mercados y la Competencia, por la que se establece la metodología y condiciones del acceso y de la conexión a las redes de transporte y distribución de las instalaciones de producción de energía eléctrica. BOE núm. 19, de 22 de enero de 2021, páginas 6111 a 6125.

[4] Resolución de 20 de mayo de 2021, de la Comisión Nacional de los Mercados y la Competencia, por la que se establecen las especificaciones de detalle para la determinación de la capacidad de acceso de generación a la red de transporte y a las redes de distribución. BOE núm. 131, de 2 de junio de 2021, páginas 67770 a 67786.

[5] Ministerio de Industria y Energía, Orden de 5 de septiembre de 1985 por la que se establecen normas administrativas y técnicas para funcionamiento y conexión a las redes eléctricas de centrales hidroeléctricas de hasta $5.000 \mathrm{kVA}$ y centrales de autogeneración eléctrica. BOE núm. 219, de 12 de septiembre de 1985, páginas 28810 a 28814.

[6] Real Decreto 413/2914, de 6 de junio por el que se regula la actividad de producción de energía eléctrica a partir de fuentes de energía renovables, cogeneración y residuos. B.O.E. núm. 140, de 10 de junio de 2014, páginas 43876 a 43978.

[7] IEEE, IEEE Guide for Planning DC Links Terminating at AC Locations Having Low Short-Circuit Capacities, IEEE Std. 12041997, 1997.

[8] NERC, Integrating Inverter-Based Resources into Low Short Circuit Strength Systems. Reliability Guideline, December 2017, disponible

https://www.nerc.com/comm/PC_Reliability_Guidelines_DL/Item 4a._Integrating\%20_Inverter-

Based_Resources_into_Low_Short_Circuit_Strength_Systems_2017-11-08-FINALL.p̄f.

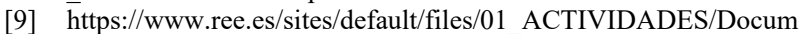
entos/AccesoRed/CAP_CON_NODAL_H2020_RIO_abr21.pdf

[10] R. Ávila-Martínez, L. Rouco, J. García Aguilar, J. Renedo, L. Sigrist, A. García-Cerrada, Impact of PLL control on small-signal stability of wind DFIGs connected to weak grids, 28 Seminario Anual de Automática, Electrónica industrial e Instrumentación, SAAEI'21, Ciudad Real 7-9 Julio 2021.

[11] Commission Regulation (EU) 2016/631 of 14 April 2016 establishing a network code on requirements for grid connection of generators, https://eur-lex.europa.eu/legalcontent/ES/TXT/PDF/?uri=CELEX:32016R0631\&from=EN

[12] Ebrahim Rahimi, Voltage Interactions and Commutation Failure Phenomena in Multi-Infeed HVDC Systems, Department of Electrical and Computer Engineering University of Manitoba, 2011.

[13] Chengjun Xia, Xia Hua, Zhen Wang and Zhenlin Huang, Analytical Calculation for Multi-Infeed Interaction Factors Considering Control Modes of High Voltage Direct Current Links, Energies, 8 June 2018.

[14] Ministerio de Industria, Energía y Turismo, Resolución de 5 de abril de 2016, de la Secretaría de Estado de Energía, por la que se aprueba el procedimiento de operación del sistema eléctrico 1.1 «Criterios de funcionamiento y seguridad para la operación del sistema eléctrico», BOE, núm. 83, de 6 de abril de 2016, páginas 24013 a 24018.

[15] Ministerio de Industria, Energía y Turismo, Resolución de 22 de marzo de 2005, de la Secretaría General de la Energía, por la que se aprueba el Procedimiento de Operación 13.1. «Criterios de Desarrollo de la Red de Transporte», de carácter técnico e instrumental necesario para realizar la adecuada gestión técnica del Sistema Eléctrico. BOE núm. 85, de 9 de abril de 2005, páginas 12351 a 12358 .

[16] Regulation (EU) 2019/943 of the European Parliament and of the Council of 5 June 2019 on the internal market for electricity, https://eur-lex.europa.eu/legalcontent/EN/TXT/PDF/?uri=CELEX:32019R0943\&from=ES.

[17] Ministerio para la Transición Ecológica y el Reto Demográfico, Orden TED/749/2020, de 16 de julio, por la que se establecen los requisitos técnicos para la conexión a la red necesarios para la implementación de los códigos de red de conexión. BOE núm. 208, de 1 de agosto de 2020, páginas 62406 a 62458.

[18] https://d1n1o4zeyfu21r.cloudfront.net/Capacidad_de_acceso_a_R dT_ED_1jul21_1.pdf.

[19] REE, Repuesto el suministro eléctrico en las zonas afectadas de España tras un incidente en la red francesa que ha generado la desconexión temporal del sistema eléctrico peninsular del resto de Europa, Nota de prensa, 24 julio 2021, https://www.ree.es/es/salade-prensa/actualidad/nota-de-prensa/2021/07/comunicado-redelectrica-repuesto-el-suministro-electrico. 